\title{
Validation in grounded theory: conversation circles as a methodological strategy
}

\author{
Validação na teoria fundamentada nos dados: rodas de conversa como estratégia metodológica
} Validación en la teoría fundamentada en los datos: rondas de dialogo como estrategia metodológica

\section{Edlamar Kátia Adamy', Denise Antunes de Azambuja Zocche', Carine Vendruscolo', José Luis Guedes dos Santos", Miriam de Abreu Almeida"II}

\author{
' Universidade do Estado de Santa Catarina. Chapecó, Santa Catarina, Brazil. \\ " Universidade Federal de Santa Catarina. Florianópolis, Santa Catarina, Brazil. \\ II' Universidade Federal do Rio Grande do Sul. Porto Alegre, Rio Grande do Sul, Brazil.
}

How to cite this article:

Adamy EK, Zocche DAA, Vendruscolo C, Santos JLG, Almeida MA. Validation in grounded theory: conversation circles as a methodological strategy. Rev Bras Enferm [Internet]. 2018;71(6):3121-6. DOI: http://dx.doi.org/10.1590/0034-7167-2017-0488

Submission: 06-29-2017

Approval: 04-13-2018

\begin{abstract}
Objective: To present the validation of a theoretical model through conversation circles in a qualitative research guided by the Grounded Theory. Method: Study carried out from a thesis developed in a reference hospital in the south region of Brazil. Two conversation circles happened, with participation of representatives of the "Training Prism", in the months of October and November, 2016. Results: The conversation circle enabled an in depth dialogic approach of the subject of research, broadening the vision on the phenomenon and on the research. The circle also mobilized thinking as it highlighted the subjectivity of individuals, expanding the group's ability of understanding and assisting in the validation process of a theoretical model. Conclusion: The conversation circle emerges as a powerful strategy for the development of qualitative research in nursing, more specifically in the validation step of the Grounded Theory.
\end{abstract}

Descriptors: Nursing; Qualitative Research; Methodology; Nursing Research; Grounded Theory.

\section{RESUMO}

Objetivo: Apresentar a validação de um modelo teórico por meio de rodas de conversa em uma pesquisa qualitativa orientada pela Teoria Fundamentada nos Dados. Método: Estudo a partir de uma pesquisa de tese desenvolvida em um hospital de referência no Sul do Brasil. Realizaram-se duas rodas de conversa com participação de representantes do "Prisma da Formação", nos meses de outubro e novembro de 2016. Resultados: A roda de conversa possibilitou uma abordagem dialógica em profundidade acerca do tema de investigação, ampliando a visão do fenômeno e da pesquisa. Mobiliza o pensamento ao destacar a subjetividade dos sujeitos, ampliando a capacidade de compreensão do grupo e auxiliando no processo de validação de um modelo teórico. Conclusão: A roda de conversa emerge como uma potente estratégia para o desenvolvimento de pesquisas qualitativas em enfermagem, mais especificamente na etapa de validação na Teoria Fundamenta nos Dados.

Descritores: Enfermagem; Pesquisa Qualitativa; Metodologia; Pesquisa em Enfermagem; Teoria Fundamentada.

\section{RESUMEN}

Objetivo: Presentar la validación de un modelo teórico por medio de rondas de dialogo en una investigación cualitativa que ha sido orientada por la Teoría Fundamentada en los Datos. Método: Estudio desde la tesis que ha sido desarrollada en un hospital de referencia en la región Sur de Brasil. Se han realizado dos rondas de dialogo con la participación de representantes del "Enfoque de Formación", en los meses de octubre y noviembre de 2016. Resultados: La ronda de dialogo ha posibilitado un abordaje dialógico en profundidad acerca del tema de investigación, ampliando la visión del fenómeno y de la investigación. La ronda también ha movilizado el pensamiento al subrayar la subjetividad de los individuos, ampliando la capacidad de comprensión del grupo y auxiliando en el proceso de validación de un modelo teórico. Conclusión: La ronda de dialogo 
emerge como una potente estrategia para el desarrollo de investigaciones cualitativas en enfermería, más específicamente en la etapa de validación en la Teoría Fundamentada en los Datos.

Descriptores: Enfermería; Investigación Cualitativa; Metodología; Investigación en Enfermería; Teoría Fundamentada.

\section{CORRESPONDING AUTHOR}

\section{INTRODUCTION}

Data-grounded theory and the purposes of qualitative research in nursing

The Grounded Theory (GT) enables the understanding of a research phenomenon from the reality in which it manifests through a thorough comparative analysis of the data and concepts that give rise to a theory. In the context of qualitative research in nursing and health, GT has gained prominence as a method that enables the understanding of experiences, meanings, and interactions among individuals inserted in a given context. To this end, the construction of the theory requires interaction between making inductions (from the specific to the broad), to produce concepts from the data, and making deductions (from the broad to the specific), to generate hypotheses on the relationships among the concepts derived from the data, from their interpretation ${ }^{(1-3)}$.

Since its conception, in the 1960s, until today, GT, as a research method, has developed by three main methodological perspectives: classical, relativistic or subjectivist, and constructivist. Each of these approaches presents specific characteristics that enable different operation modes, based on its own epistemological concepts and paradigms, resulting from the evolution of the process of construction of scientific knowledge ${ }^{(1,3)}$.

In the constructivist approach, GT can generate possibilities to construct reliable knowledge in nursing, whose study objects involve human interactions, seeking to develop an interactive and complex care when facing contemporary problems ${ }^{(1-2)}$. The constructivist GT is based on the assumption that both the data and the analyses are social constructions that reflect what is determined by the involvement and interaction with people, in which the perceptions and expressions of the research participants are reflections of the reality. Constructivism promotes reflexivity for the researchers regarding their own interpretations, as well as the participants' interpretations ${ }^{(2)}$.

Among the steps for developing a GT, validation is important to analyze the relevance and representativeness of the study concerning the investigated phenomenon. For this, it is recommended to discuss with the participants about the categories generated from the data and also about GT representative theoretical model. Data validation allows the researcher to seek information to develop a more complete explanation, thus enabling the research to be further developed or properly redirected ${ }^{(2)}$. Therefore, with validation, it is possible to analyze if the theoretical model represents the investigated reality, as well as discuss its applicability to other contexts of time and space, allowing modifications and additions of new elements, aiming to improve the interpretation of the investigated phenomenon ${ }^{(1,3)}$.

Among the strategies that could be used to validate the data and the theoretical model in GT, aiming at the co-construction of a theory along with the participants, we opted to carry out a conversation circle. The conversation circle is a collective resonance method, consisting in creating spaces for dialogue, in which people express themselves, listen to others and to themselves, thus stimulating the construction of these individuals' autonomy by questioning, sharing information, and reflecting before acting. In Brazil, it is possible to notice the increased use of conversation circles in academic projects and constructivist educational processes ${ }^{(4)}$.

In the Brazilian nursing scientific literature on GT, there are studies that discuss, for example, conceptual and operational aspects of the method ${ }^{(5)}$, the researcher's characteristics and abilities to develop the research, and differences between GT methodological approaches ${ }^{(1,3,5)}$. However, none of the studies specifically describe the step of validation of the theoretical model in $\mathrm{GT}^{(2)}$, neither the use of conversation circles. Therefore, we highlight the relevance of this paper, which may aid researchers interested in using the GT for research in nursing and health.

Furthermore, this study is also justified by the need to socialize to peers different experiences regarding the production of knowledge in nursing and health, particularly in qualitative research. The presentation of new research strategies to the scientific community, specifically regarding methodological paths and production of empirical data, is an integral part of the work of a researcher ${ }^{(6)}$.

Given these prerogatives, this paper aimed to present the validation of a theoretical model through conversation circles in a qualitative research guided by the GT.

\section{OBJECTIVE}

To present the validation of a theoretical model through conversation circles in a qualitative research guided by the GT.

\section{METHOD}

\section{Entering the circle}

This study is an experience report about the validation strategy of a theoretical model adopted in the thesis titled Formação em serviço acerca do processo de enfermagem na perspectiva da integração ensino-serviço: o modelo do Hospital de Clínicas de Porto Alegre (HCPA) [In-service training regarding the nursing process in the perspective of teaching-service integration: the model of the Clinical Hospital of Porto Alegre (HCPA)], developed with the Graduate Program in Nursing of the Federal University of Rio Grande do Sul (UFRGS) ${ }^{(7)}$. The research aimed to "understand the constitution of the model of in-service training regarding the nursing process in the perspective of teachingservice integration". To this end, we used constructivist GT as the methodological referential and symbolic interactionism as the theoretical referential. 
The study setting, the Clinical Hospital of Porto Alegre (HCPA), is a public general institution with ties to the university, linked to the Ministry of Education and the UFRGS.

Participants were defined based on the concept of theoretical sampling proposed by GT. Theoretical sampling implies obtaining the data, build provisional ideas, and then analyze these ideas through a new empirical research ${ }^{(2)}$. Participants were twelve individuals who represented the segments of the "health training prism". The "prism" is a metaphor that broadens the idea of the training square, in which the individuals and represented segments (teachers, users, administrators, and employees) are involved in diverse situations and realities, which impact on the way to exercise this representation and, therefore, deliberate on the most varied situations ${ }^{(8)}$. For this study, the following professionals participated in the research: a healthcare nurse; a nurse professor of the undergraduate course in nursing of UFRGS; a student of the penultimate semester of the undergraduate course in nursing of UFRGS; a nurse from the Multidisciplinary Residency in Health; a nurse responsible for the technical aspects; a nurse representing the Nursing Education Service and the Nursing Process Commission; and a nurse representing the Nurses Association of the HCPA (AE/HCPA).

The processes of data collection and analysis were carried out concurrently, as suggested by the $\mathrm{GT}^{(2)}$. For the data collection, we used the intensive interview technique, which allows the interviewer to go beyond the appearances of the described experience. The analysis of the interviews followed the methodological guidance of the GT, which uses an encoding process to reduce the data that, initially, constitute preliminary codes, becoming conceptual codes and, later, the categories that can converge into phenomena ${ }^{(2)}$.

In the investigated scenario, "prism" participants established a relationship with each other to form the theoretical model from the meanings, interaction, and subjectivity of each individual, also taking into consideration the collective actions of teaching-service integration and the assumptions of the Permanent Education in Health, which guide such movements. It should be noted that these participants, although representatives of a segment of the prism, are individuals with their own conceptions about the proposed theme, due to their experiences as social human beings, nurses, teachers, students, and administrators, which can interfere in other segments and with each other ${ }^{(8)}$. From their ideals, we were able to analyze the relevance and representativeness of the study concerning the investigated phenomenon, by the discussions about the categories generated from the data and the GT representative theoretical model representative.

During the analysis, we felt the need of producing a space for data validation data and of a theoretical model that met the rigor of a qualitative research. It is important to remember that GT has a dynamic movement, which allowed to identify the validation strategy through the conversation circles, as it has a characteristic that responds to the study's needs, providing a space and moment of reflection for the consolidation of ideas. In other words, the conversation circles emerges as a validation strategy due to its dialogic and dynamic character, corresponding to the GT methodology.
Four individuals participated of the validation, representing the "training prism" (a healthcare nurse, a administrator, a representative of the $\mathrm{AE} / \mathrm{HCPA}$, and a nursing student), with knowledge and experience about the nursing process, thus allowing the validation process. It should be noted those who participated in the validation stage were not interviewed during data collection.

For the validation, two conversation circles were carried out with professionals who represented the "training prism". The circle's participants were invited via e-mail and the meetings were previously scheduled. The first happened at the School of Nursing and the second on the premises of HCPA, both lasted for about one hour, at an environment that favored secrecy and fit the number of participants.

The participants sat in a circle, so that everyone could see the others when talking, thus expressing ideas and feelings about the addressed topic. The circle mediator (researcher) also participated in the conversation, in order to resume points, clarify ideas, explain issues that could be ambiguous, or permeate the dialogue. The interventions were free, there was no rigidity regarding the direction of the conversation, as we believe that everything the circle talked about has a sense, a meaning that the group will work with, face, assimilate, or leave out.

The validation period, through the conversation circle, happened in the months of October and November, 2016. All information of the conversation circle were recorded in audio with the consent of the participants.

The research project was approved by the Research Ethics Committee of the School of Nursing of the UFRGS and by the Research Ethics Committee of HCPA.

\section{Results and discussion: a myriad of knowledge validated in the conversation circle}

The group dialogue was developed among agreements and disagreements concerning the presented data. New questions have also emerged, which contributed to consolidate the theoretical model. During the conversations, discussions on the objective and the research results were prioritized, in a dialogic process, in which the individuals talked about their vision regarding the theoretical model to validate it.

Dialogue promotes a joint accountability of those involved in the process when it comes to the strengthening of the teachingservice integration ${ }^{(9)}$. The dialogue is a basic condition for the construction of knowledge in practice, from the communication between individuals, which shall, consequently, generate individual and social transformations. It should be highlighted that, in this respect, listening and speaking are conditions for the dialogic communication between social individuals with different opinions. From such a move, there are times when the discipline of silence must be assumed rigorously, when there is interest in another person's knowledge ${ }^{(10-11)}$.

In this sense, validation comprehended the following system: in the first meeting, the objectives of the conversation circle and of the study were explained and the informed consent form was read and signed. In a second moment, the paths taken and the guiding themes were presented to start the conversation. Then, the individuals were motivated to give their opinion about 
the data and composition of the in-service training model presented by the researcher. This deeper reflection configured as validation of the theoretical model of in-service training, since the participants suggested a new meeting to reflect on another proposal, which emerged from the weaknesses and the need to broaden the representative diagram of the exposed model. However, there was consensus about the categories that supported the research phenomenon.

In the second conversation circle, the validation process of the theoretical model of in-service training continued, reformulated by a representative diagram of this model. At this time, changes were suggested in the structure of the training model and in the representative diagram of the educational activities, so that both represented, from the diagrams, the thesis being discussed. It should be noted that the generated model is characterized as a substantive theory, i.e., a specific theory for a particular group or situation, developed from the data, with no goal of generalization beyond its substantive area ${ }^{(1-2)}$. Chart 1 presents a synthesis of the operationalization of the two conversation circles.

Regarding educational practices, of care or management, conversation circles have been established as strategies to reflect on the work processes ${ }^{(4,12)}$. In the context of health services, they can be considered methodological strategies of health promotion actions, of self listening, and self and collective care. The circle method proposes the idea to "think the constitution of the individual and of collectivities according to plans placed between their inner world and the circumstances - outside world"(4).

From this point of view, the circle allows for trading spaces, in which learning is mediated for the development of skills, so that all who enter the circle have equal powers regarding the subject being discussed ${ }^{(6)}$. It can also be considered a strategy to develop qualitative research, in which the space of exchanging, sharing, and developing knowledge appears as a device of empowerment, strengthening the professional autonomy, and also as a space of (re)signifying professional values, standards, and practices.
Authors such as Paulo Freire mention the space produced in circles, to integrate and aggregate all in the same position, i.e,. of apprentices. In this context, the space of the circle boosts the construction of new possibilities open to the thinking, in a continuous movement of understanding-reflecting-acting-changing, in which participants can recognize themselves as conductors of their actions ${ }^{(10-13)}$. Therefore, when used as a research tool, the circle is a strategy not only to collect and validate data, but above all, to intervene. Within the circle, conversations are produced, thus it is necessary to be open to the dialogue, so that everyone can feel free to share and listen. Thus, what is said, what is spoken, may be (re)signified, reviewed, understood, making the moment relevant to the group and raising the attention to what is said.

The dialogue is a singular moment of sharing for being an exercise of listening and talking, involving several conversation partners, with listening moments being more numerous than talking ones. The perceptions of each individual are constructed through the interaction with the other, either to complement, disagree, or agree with what is said, since the conversations in the circle spaces allow the individual to more deeply understand the dialogue, the reflection, and the deliberation, in the sense of sharing the information ${ }^{(10)}$.

The notion of circles and networks is present in the formulations in education and learning, as the circle is constituted by a working and debate group ${ }^{(10)}$. For Freire, education, as a relationship between cognitive individuals, mediatized by cognizable objects, is an action that generates questioning, in which both students and teachers are questioned. In this educational method, each movement of the individual, to deepen himself in a critical situation, opens up new possibilities to understand the object of analysis to other individuals ${ }^{(10)}$. In this sense, the relations that intend to be fruitful, creative, based on alterity, whose concept implies the possibility of putting oneself in the place of the other, dialogical, without, however, erasing the other's creativity are favored ${ }^{(8)}$.

Chart 1 - Operationalization of the two conversation circles according to objective, participants, steps, and result

\begin{tabular}{|c|c|c|}
\hline & Conversation circle 1 & Conversation circle 2 \\
\hline Date & October, 2016 & November, 2016 \\
\hline Objective & $\begin{array}{l}\text { To present the categories, the diagrams, and the study's theoretical } \\
\text { model }\end{array}$ & To validate the theoretical model \\
\hline Participants & Four & Four \\
\hline Steps & $\begin{array}{l}\text { - Presentation of the objectives of the study and conversation circle. } \\
\text { - Presentation of the methodological approach. } \\
\text { - Reading and requesting of signing of the informed consent form. } \\
\text { - Data interpretation and validation of codes. } \\
\text { - Presentation of the phenomenon, categories, and representative } \\
\text { diagrams. }\end{array}$ & $\begin{array}{l}\text { - Representation of the phenomenon, categories, } \\
\text { and representative diagrams. }\end{array}$ \\
\hline Result & $\begin{array}{l}\text { - There was consensus as to the phenomenon, categories, and } \\
\text { subcategories. } \\
\text { - The individuals pointed out weaknesses and the need to expand the } \\
\text { representative diagram of the educational actions and theoretical } \\
\text { model. } \\
\text { - The individuals suggested new meetings. }\end{array}$ & $\begin{array}{l}\text { The individuals suggested minor changes in the } \\
\text { relationship between the educational actions and } \\
\text { their structure in the representative diagram of } \\
\text { the educational actions and training theoretical } \\
\text { model. } \\
\text { - There was consensus regarding the representation } \\
\text { of the phenomenon in the theoretical diagram. }\end{array}$ \\
\hline
\end{tabular}


In this dialogical construction, circles produce collective and contextualized knowledge by favoring critical speaking and sensitive listening ${ }^{(13)}$, thus enabling interaction between the participants and sharing of information, which favored the validation of the theoretical model of in-service training of $\mathrm{HCPA}$ regarding the nursing process.

Within the scenario of this research, circle discussions allowed us to validate the data that emerged from the data collected through the intensive interviews. The conversation circle proved useful to validate the model in a research using GT, as it allowed the participants to manifest their impressions about the investigated phenomenon, in a light and dialogical way, configuring itself as a constructive process from a myriad of impressions. Thus, it demanded a sharper perception on the part of the researchers about the analyzed theme, allowing the broadening of their vision on the phenomenon, since the participants had extensive knowledge, which expanded the research limits. In this sense, the circle worked as a dance, allowing participants to express themselves and exercise their critical role in validating the theoretical model.

The debate about the categories and about the research phenomenon through a conversation circle, giving the circle the dialogue that sustains the thesis, allowed us to reaffirm the movements provoked by the construction of the educational processes within the research. The circle enhances thought, highlighting the individual's subjectivity and the researcher's ability to understand and interpret, in a collective way. In this regard, it should be highlighted that, in addition to emerging the individuals' subjectivity, the circle allowed the discussion of their identities submerged in this subjectivity, which are reflected in their care practices. This resulted in the structuring of the Nursing Process, culminating with the quality of the care provided and strengthening of the professional identity.

Concerning the dialogic process, favored by this methodological structure, it is worth remembering that educational movements favor the relations between the individuals involved in the process, implying the commitment and accountability of each participant ${ }^{(8)}$. The levels of involvement of the different individuals who participated in the circle were essential to establish fruitful relations, as well as to break with the established spaces of each social actor of the prism. Thus, effective circles or networks were built, concerning health care, in which all those involved are implicated in the pursuit of innovative actions, confirming that the teaching-service integration is essential to strengthen this and other constructs, regarding care qualification, in this case, of the Nursing Process.

Through dialogue, the human being becomes aware and realizes the possibility of growth, becoming critical and reflective. In this movement, new knowledge are sought, in which all learn and teach jointly, seeking to understand the common problems of everyday life ${ }^{(10)}$. Therefore, it is essential that the individuals implicated in this process (prism) transcend their individual projects of knowledge/power, emerging in professional and institutional thoughts, dedicating themselves to obtain new and more effective ways to produce health ${ }^{(8)}$.

Science is made when the researcher discusses the phenomena by applying technical resources, following a method and resorting to epistemological foundations. Thus, thinking about the limits and possibilities of the circle as a methodological strategy, not only to validate, but also to produce information in qualitative research, we believe that, among the challenges is the impossibility of all participants to be present in the proposed times. As potentiality, we highlight, beyond what has already been presented, the coherence of the methodology with the idea of depth, which meets the assumptions of qualitative research, as well as the scientific rigor.

Finally, it should be noted that, in addition to the method, clarity is necessary to research in the area of health, especially in nursing. Studies should be concerned with relevant issues to the nursing work process, aiming at quality of care and guided for the construction of technological, scientific and human knowledge in the area.

\section{FINAL CONSIDERATIONS}

The conversation circle, in the context of educational, care, management and health promotion practices, is already consolidated. In the field of qualitative research in nursing, more specifically in GT, the conversation circle emerges as an effective strategy to validate the data and the theoretical model, as well as as an important tool to produce qualitative data.

We envision conversation circles as potent alternatives to qualitative studies to value the credibility of the findings and analyses, configuring themselves as dialogic and creative spaces of exchange, sharing, and development of knowledge, to empower the involved individuals, as well as to strengthen their professional autonomy.

We consider that using the strategies of the conversation circle was essential to collect and validate the data from the research that illustrates this experience, because the GT, as a research method, demanded the return to the field, making it possible to build a theoretical model that represented the studied phenomenon.

\section{FUNDING}

This study was funded by the Coordination of Higher Education and Graduate Training (Capes), in a project of Inter-institution PhD (Dinter), in partnership with the Graduate Program in Nursing of UFRGS.

\section{REFERENCES}

1. Santos JLG, Erdmann AL, Sousa FGM, Lanzoni GMM, Melo ALSF, Leite JL. Methodological perspectives in the use of grounded theory in nursing and health research. Esc Anna Nery[Internet]. 2016[cited 2016 Nov 20];20(3):e20160056. Available from: http:// www.scielo.br/pdf/ean/v20n3/en 1414-8145-ean-20-03-20160056.pdf 
2. Charmaz K. A construção da Teoria Fundamentada: guia prático para análise qualitativa. Porto Alegre: Artmed; 2009.

3. Kenny M, Fourie R. Contrasting Classic, Straussian, and Constructivist Grounded Theory: methodological and philosophical conflicts. Qualit Rep[Internet]. 2015[cited 2017 Mar 10];20(8):1270-89. Available from: http://nsuworks.nova.edu/tqr/vol20/iss8/9

4. Campos GWS. Um método para análise e co-gestão de coletivos: a constituição do sujeito, a produção de valor de uso e a democracia em instituições: o método da roda. São Paulo: Hucitec; 2000.

5. Silva MM, Moreira MC, Leite JL, Stipp MAC. A Teoria Fundamentada nos Dados nos estudos de pós-graduação stricto sensu da enfermagem brasileira. Rev Eletron Enferm[Internet]. 2011[cited 2016 Nov 20];13(4):671-9. Available from: https://www.fen.ufg. br/fen_revista/v13/n4/pdf/v13n4a11.pdf

6. Soratto J, Pires DEP, Cabral IE, Lazzari DD, Witt RR, Sipriano CAS. A maneira criativa e sensível de pesquisar. Rev Bras Enferm[Internet]. 2014[cited 2016 May 1];67(6):994-9. Available from: http://www.scielo.br/pdf/reben/v67n6/0034-7167-reben-67-06-0994.pdf

7. Adamy EK, Almeida MA. Formação em serviço acerca do processo de enfermagem na perspectiva da integração ensino-serviço: o modelo do HCPA[Tese]. Porto Alegre: Universidade Federal do Rio Grande do Sul; 2016.

8. Vendruscolo C, Prado ML, Kleba ME. Reorientação do ensino no SUS: para além do quadrilátero, o prisma da educação. Rev Reflex Ação[Internet]. 2016[cited 2017 Jan 10];24(3):246-60. Available from: https://online.unisc.br/seer/index.php/reflex/article/ view/5420/pdf

9. Vendruscolo C, Ferraz F, Prado ML, Kleba ME, Reibnitz KS. Teaching-service integration and its interface in the context of reorienting health education. Interface[Internet]. 2016[cited 2017 Jan 10];20(59):1015-25. Available from: http://www.scielo.br/pdf/icse/v20n59/ en_1807-5762-icse-1807-576220150768.pdf

10. Freire P. Pedagogia do oprimido. 17. ed. Rio de Janeiro: Paz e Terra; 1987.

11. Freire P. Pedagogia da autonomia: saberes necessários à prática educativa. 43. ed. São Paulo: Paz e Terra, 2011.

12. Costa RRO, Bosco Filho J, Medeiros SM, Silva MBM. As rodas de conversas como espaço de cuidado e promoção da saúde mental. Rev Atenção Saúde[Internet]. 2015[cited 2017 Mar 10];13(43):30-6. Available from: http://seer.uscs.edu.br/index.php/ revista_ciencias_saude/article/view/2675/pdf_1

13. Sampaio J, Santos GC, Agostini M, Salvador AS. Limites e potencialidades das rodas de conversa no cuidado em saúde: uma experiência com jovens no sertão pernambucano. Interface[Internet]. 2014[cited 2016 Aug 12);18(suppl-2):1299-311. Available from: http://www.scielo.br/pdf/icse/v18s2/1807-5762-icse-18-s2-1299.pdf 